\title{
Environmental Assessment in the Arctic: A Gap Analysis and Research Agenda
}

\author{
Bram Noble ${ }^{1}$ and Kevin Hanna ${ }^{2}$
}

(Received 7 November 2014; accepted in revised form 21 January 2015)

\begin{abstract}
Environmental assessment (EA) is employed across the Arctic to assess, mitigate, and monitor the impacts of resource development. Despite the increasing pressures of resource development on Arctic communities and ecosystems and the growing demands for more efficient and effective EA processes, little is known about the needs and priorities of research that will help us to understand and improve EA and its relevance to Arctic communities. A gap analysis of EA research across eight Arctic nations, based on a review of the scholarly literature, government research and policy documents, and a questionnaire survey of Arctic EA scholars, addressed both project-based EA and strategic EA that focused on policy, planning, and regional assessment. Results indicate seven priority research themes: understanding community and stakeholder expectations about EA; assessing the efficiency and responsiveness of EA to rapidly changing socio-ecological and regulatory environments; examining the influence of EA on development decisions; addressing the capacity for meaningful engagement in EA; strengthening the relationship between EA and land-use planning and Arctic science programs; demonstrating the value of regional EA; and assessing the ability of EA to respond to the reality of climate change. These are not the only areas where further EA research is needed, but they are critical to the effectiveness of EA in the Arctic and to ensuring its relevance to Arctic communities.
\end{abstract}

Key words: environmental assessment; Arctic environmental assessment; gap analysis; environmental assessment effectiveness

RÉSUMÉ. Des évaluations environnementales (EE) sont réalisées à l'échelle de l'Arctique dans le but d'évaluer, d'atténuer et de surveiller les incidences de l'exploitation des ressources. Malgré les pressions accrues qu'exerce la mise en valeur des ressources sur les communautés et les écosystèmes de l'Arctique, et malgré la demande croissante pour des processus d'EE plus efficaces, nous en savons peu sur les besoins et les priorités de recherche qui nous aideront à comprendre et à améliorer les EE et leur pertinence dans les communautés de l'Arctique. L'analyse des écarts en matière de recherche sur les EE dans huit nations de l'Arctique, analyse fondée sur des articles scientifiques, des travaux de recherche réalisés par les gouvernements, des documents de politiques et un sondage auprès de spécialistes des EE dans l'Arctique, a porté tant sur les EE de projets que sur les EE stratégiques axées sur les politiques, la planification et les évaluations régionales. Les résultats de cette analyse ont fait ressortir sept thèmes de recherche prioritaires : comprendre les attentes des communautés et des parties prenantes en matière d'EE; évaluer l'efficacité et la réactivité des EE vis-à-vis des milieux réglementaires et socioécologiques évoluant rapidement; examiner l'influence qu'exercent les EE sur les décisions en matière de mise en valeur; déterminer la capacité d'une participation significative dans les EE; renforcer la relation entre les EE, la planification de l'utilisation des terres et les programmes scientifiques menés dans l'Arctique; faire comprendre l'importance de réaliser des EE régionales; et évaluer l'aptitude des EE à réagir à la réalité du changement climatique. Non seulement il s'agit là d'aspects pour lesquels il faut pousser plus loin la recherche sur les EE, mais aussi d'aspects qui revêtent une importance primordiale quant à l'efficacité des EE dans l'Arctique et à leur pertinence pour les communautés de l'Arctique.

Mots clés : évaluation environnementale; évaluation environnementale de l'Arctique; analyse des écarts; efficacité de l'évaluation environnementale

Traduit pour la revue Arctic par Nicole Giguère.

\section{INTRODUCTION}

Since the late 20th century, the Arctic has been increasingly exposed to energy and mineral resource extraction, expanding transportation networks, growing non-indigenous settlements, the impacts of climate change, and the growing presence of persistent organic pollutants (Prowse et al., 2009; Burkett, 2011; Porta and Bankes, 2011). The United Nations Environment Programme GLOBIO Report indicates that by 2050, even at modest rates of economic growth, approximately $50 \%$ to $80 \%$ of the Arctic may reach

\footnotetext{
${ }^{1}$ School of Environment and Sustainability, University of Saskatchewan, 117 Science Place, University of Saskatchewan, Saskatoon, Saskatchewan S7N 5C8, Canada; b.noble@usask.ca

${ }^{2}$ Centre for Environmental Assessment Research, The University of British Columbia, Fipke Centre for Innovative Research,

3427 University Way, Kelowna, British Columbia V1V 1V7, Canada; kevin.hanna@ubc.ca

(C) The Arctic Institute of North America
} 
critical levels of anthropogenic disturbance (Nellemann et al., 2001). Environmental assessment (EA) is applied globally to a range of resource development activities and initiatives at various scales, and it is the primary instrument for assessing and managing the impacts of resource development in the Arctic. The 1991 Strategy for the Protection of the Arctic Environment emphasized the importance of EA, leading to the establishment of the Arctic Monitoring and Assessment Programme (AMAP) and, subsequently, the adoption of Arctic guidelines for EA under the 1997 Alta Declaration by the ministers of Arctic countries (Arctic Council, 1997). The AMAP (2007) recommends that EA and related planning tools, including strategic EA, be rigorously applied in the Arctic and that attention be directed toward increasing their relevance and usefulness. In a review of Arctic guidelines for EA, Koivurova (2008) reports that EA will likely become one of the most crucial management tools in the Arctic, but at the same time cautions that, to date, guidelines for ensuring effective Arctic EA have not proven successful.

Koivurova's (2008) observation is not surprising. In recent years, the effectiveness of EA has been questioned globally (Fuggle, 2005; Morgan, 2012; Bond et al., 2014) and particularly in the Arctic (Pölönen et al., 2011; Doelle et al., 2012; Noble et al., 2013). In the Finnish context, for example, Pölönen et al. (2011) identify the linkages between EA and decision-making processes as a major deficiency, and in Russia, Cherp and Golubeva (2004) report several challenges in national-level approaches to EA implementation. In Canada's western Arctic, Noble et al. (2013) and BSStRPA (2008) identify challenges to current EA processes in capturing the cumulative effects of energy developments, whilst Harrison (2006) and Voutier et al. (2008) report the challenges to industry arising from what is claimed to be an overly complex EA regulatory environment. Given the emerging and enduring concerns about the effectiveness of EA, coupled with increasing pressures on Arctic communities and ecosystems, there is a need for the international EA research community "...to better identify the benefits as well as costs of impact assessment" (Boyden, 2007:3). Practitioners, proponents, communities, and governments understandably want to know if the time and resources spent on EA are actually leading to improved environmental management and environmental quality (Chanchitpricha and Bond, 2013); however, the majority of research on EA, particularly research on its effectiveness, has taken place outside the Arctic (e.g., Appiah-Opoku, 2001; Cashmore et al., 2004; Heinma and Pöder, 2010; Che et al., 2011; Hanna and Noble, 2011; Bond et al., 2014). The recent gap analysis report prepared under the Strategic Environmental Impact Assessment of Development of the Arctic initiative (Tedsen et al., 2014) provides a useful synthesis of the Arctic information needs of stakeholders and policy-makers and identifies opportunities to reduce information and communication gaps, but to advance Arctic EA, an understanding of the research focus of the Arctic EA scholarly community is also needed.
Our work is part of the larger Resources and Sustainable Development in the Arctic project, which aims to help Arctic communities identify and mitigate the adverse impacts of resource development. In this paper, we examine what work has been done to understand how effective EA is in the Arctic and identify key gaps in research that must be addressed to improve EA and its relevance to communities across the Arctic.

\section{ENVIRONMENTAL ASSESSMENT AND NATIONAL CONTEXTS}

Environmental assessment is broadly defined as a process for identifying, predicting, evaluating, and mitigating the biophysical, social, and other relevant effects of development proposals before major decisions and commitments are made (IAIA and IEA, 1999). Often described as an environmental protection tool, a methodology, and a regulatory requirement, EA is most importantly a process designed to aid decision making, through which concerns about the potential environmental consequences of proposed actions, public or private, are incorporated into decisions regarding those actions. In this regard, EA can also be viewed as a means of strengthening environmental management processes (Morrison-Saunders and Bailey, 1999). The underlying intent of EA is to enable proponents, communities, and decision makers to increase the benefits and minimize the environmental costs of development actions. In this sense, EA is both a planning tool and a management tool for choosing and designing developments wisely. It can also be viewed in a much broader context: as a means to influence decisions and to provide an opportunity for public debate about the merits of a proposed development.

Environmental assessment is now "universally recognized as a key instrument for environmental management, firmly embedded in domestic and international environmental law" (Morgan, 2012:6). Below we provide a brief overview of the EA setting in the eight Arctic nations: the United States (Alaska), Canada, Russia, Finland, Sweden, Denmark (Greenland), Iceland, and Norway. The history, provisions, scope, and requirements of EA vary considerably across the Arctic. For example, the United States, Canada, and Russia have both national EA systems and varying EA mandates based on territorial, state, or other administrative sub-jurisdictions, including specific provisions and rights granted to indigenous peoples. Further, except for certain sub-jurisdictions (e.g., Norway's Svalbard Islands, Canada's Inuvialuit Settlement Region), the majority of EA systems across the Arctic do not contain Arcticspecific provisions (Koivurova, 2008). Our objective here is to provide context to the diversity of EA systems across the Arctic, rather than to explore in detail the provisions and operations of each system. However, common to all EA systems in the Arctic is the provision of adequate information about the potential impacts of proposed development actions to support informed decision making. 
Environmental assessment in the Arctic was first introduced by way of the 1970 National Environmental Policy Act (NEPA) in the United States. The state of Alaska applies NEPA procedures, and the Alaska Department of Natural Resources is responsible for coordinating the state permitting process for NEPA assessments. In the offshore regions, including the Beaufort and Chukchi Seas, the Bering Sea, Cook Inlet, and the Gulf of Alaska, the federal Bureau of Ocean Energy Management is responsible for NEPA analysis and related EA studies. There is no formal strategic EA system in Alaska, but NEPA does provide for programmatic EAs of offshore multi-project activities and programs or specific offshore areas, such as the programmatic EA of the Arctic Ocean outer continental shelf seismic surveys (U.S. DOI MMS, 2006).

In Canada, EA was first introduced in 1972 by way of a federal policy requiring that all federally initiated projects, and those projects under federal jurisdiction, be screened for potential pollution effects. It was the Mackenzie Valley Pipeline Inquiry (Berger, 1977) that, although not formally an EA, "set an international standard for critical and cross-cultural public assessment" and created expectations "about what an assessment process should be"-not only in the Arctic, but also globally (Gibson and Hanna, 2009:22). Environmental assessment in the Canadian Arctic is a complex and sometimes overlapping system of federal jurisdiction (under the Canadian Environmental Assessment Act, 2012) and territorial EA systems (e.g., the Yukon Environmental and Socio-economic Assessment Act). Canada's territorial EA systems have also developed from the settlement of comprehensive land-claim agreements with Aboriginal groups and are administered under a variety of regional boards and agencies, such as the Mackenzie Valley Environmental Impact Review Board, the Nunavut Impact Review Board, and the Western Arctic Environmental Impact Screening Committee and Environmental Impact Review Board. Thus the administration of these EA processes is distinct from that of Canada's provincial EA systems. Through various co-management boards and committees, EA in Canada's Arctic is arguably more integrated into regional resource development planning than it is in the country's southern jurisdictions.

Russia's EA system is governed under the Federal Law on Ecological Expertise, 1995 (commonly referred to as "state environmental review"), the Regulation on the Assessment of Environmental Impact, 2000, and the Federal Law on Environmental Protection, 2002. Environmental assessment in each of Russia's five Arctic regions (Arkhangelsk, Karelia, Komi, Murmansk, and Nenets Autonomous Okrug) is largely influenced by federal EA regulations (Koivurova, 2008). The Russian EA process is defined as a process encouraging ecologically informed administrative decisions about the implementation of economic and other activities through identification of possible adverse impacts, assessment of ecological impacts, taking public opinion into account, and developing measures to mitigate and prevent negative impacts. It is designed for project-level developments and provides a conceptual regulatory approach to project review and permitting (Cherp and Golubeva, 2004; Solodyankina and Koeppel, 2009). Projects subject to mandatory EA include all large-scale energy, industry, and agricultural facilities. There is no strategic EA system in Russia.

Finland and Sweden are member states of the European Union (EU) and thus adopt the EU Directives on Environmental Impact Assessment (EIA; 2011/92/EU) and Strategic Environmental Assessment (SEA; 2001/42/EC). These directives set out the principles and procedures of EA and strategic EA and establish minimum requirements to ensure that the environmental impacts of certain undertakings are identified and assessed at the planning stage. However, the directives are general, allowing member states to exercise broad discretion about how to incorporate them into national legislation and what form and content that EA will take. For example, in addition to projects listed under the EU EIA Directive, the Finnish EIA Decree (713/2006) lists further types of projects that must always be subjected to EA; however, EA may also be required for any projects that the responsible regional Finnish environment authority views as likely to have adverse environmental impacts (Jantunen, 2011). The EU directives do not prescribe how EAs should be completed, nor do they contain requirements related to their quality (Pölönen, 2006).

Although Denmark is an EU member, Greenland, as a self-governing territory of Denmark, is not subject to EU directives and has established its own EA provisions under its Home Rule government. Under Greenland's Mineral Resources Act, applications for certain mineral exploration and development projects, including offshore hydrocarbon activities, require both an EA and a strategic social impact assessment. Before new offshore areas are opened up for hydrocarbon exploration and licensing, a "strategic environmental impact assessment" is also prepared by the National Environmental Research Institute, the Greenland Institute of Natural Resources, and the Mineral License and Safety Authority.

Iceland's Environmental Impact Assessment Act was introduced in 1994, when Iceland joined the European Economic Area (EEA). The 1994 Act, under which EU Directive on EIA 1985/337 became law in Iceland, was amended in 2000 and 2005 to align with changing EU requirements. The Icelandic National Planning Agency is the state authority responsible for the administration of the EA Act. Among the purposes of EA under Icelandic state legislation are to minimize the negative environmental impacts of developments and promote the cooperation of stakeholders and other interested parties concerning projects that are subject to assessment. In 2005, the locus of environment-related decision making was shifted to local authorities, allowing the National Planning Agency to focus on assessing impact rather than deciding whether projects should proceed (OECD, 2014). Informally, strategic EA in Iceland has been part of municipal land-use planning since the 1990s. The EU SEA Directive (2001/42/EC) was formally incorporated 
in 2006 in the Icelandic Act on Environmental Assessment of Plans and Programmes, which follows the main principles of the EU SEA Directive (OECD, 2014).

Norway's first EA legislation was implemented in 1990, as part of the Planning and Building Act. As a member of the EEA, Norway, like Iceland, has adopted the provisions of the EU directives. However, the Svalbard Islands, which were excluded from the EEA agreement, have their own EA procedure enacted by Norway (Koivurova, 2008). EA provisions for Norway's offshore oil and gas activities are contained in the petroleum legislation administered by the Ministry of Petroleum and Energy, which also provides for regional EAs before offshore areas are made available for licensing. In 2006, Norway introduced an additional framework, an Integrated Management Plan, to guide EA activities and offshore planning processes across the oil and gas, shipping, and fishing sectors (Fidler and Noble, 2012).

\section{APPROACH TO THE GAP ANALYSIS}

Our gap analysis was based on a survey of recent scholarly research on EA in Arctic regions, a review of select government research and policy documents, and a questionnaire survey of a small sample of EA researchers. Published journal papers addressing EA in the Arctic were identified by searching the Scopus database from 1900 to the present by title, keywords, and subject. We chose the Scopus database for its indexing, scope of coverage, and advanced search options (Baykoucheva, 2010). This search attempted to capture the range of EA terminologies. The search strategy was based on the following criteria:

i) The title of the paper must contain the phrase "environmental assessment(s)" or "environmental impact assessment(s)" or "cumulative effects assessment(s)" or "regional environmental assessment(s)" or "impact assessment(s)." This is an inclusive approach, in that the search term "impact assessment," for example, captures various types of impact assessment (e.g., social, environmental, health, biodiversity, and economic), and "environmental assessment" also captures "strategic environmental assessment."

ii) The search was then restricted to abstracts that contained the word "Arctic" or "north(ern)" or "circumpolar" or "polar" or mentioned any one of eight Arctic nations (Canada, Finland, Denmark, Iceland, Norway, Russia, Sweden, United States) or their respective regional, state or territorial EA jurisdictions (e.g., Alaska, Svalbard, Nunavut, Greenland, and so on). This study does not analyze specific jurisdictions or their local issues; the jurisdictions were included in our search only to help limit the scope of results to papers that focus on EA in the Arctic.

If one of the key search terms did not appear in the title, or if one of the key geographic or jurisdictional terms did not appear in the abstract, then the paper was excluded from our review. This is not to say that EA in the Arctic was not discussed in the paper, but rather that it was not considered the paper's focal point. This search may not have captured all scholarly literature; however, it is a good sample from which to synthesize key work that has been done on EA and identify major research themes and gaps.

In order to better identify key research issues and priorities noted also in the regulatory or professional practice literature, we also examined a selection of recent technical reports and regulatory reviews of EA system performance (e.g., Koivurova, 2002; National Research Council, 2003; Ovind and Sneve, 2004; OECD, 2006, 2014; McCrank, 2008; Tedsen et al., 2014) found by searching the websites of the respective EA jurisdictions. A content analysis approach was used to identify recurrent and unique themes in the research literature on EA in the Arctic (see Creswell, 2013).

The results from the literature survey identified a range of EA research gaps and potential priority research areas. First we identified research gaps and priorities on the basis of knowledge and information considered "missing" from Arctic EA research when examining current issues facing the Arctic (e.g., regulatory change, energy development, climate change, adaptation, cumulative effects, social change) (see Nellemann et al., 2001; Prowse et al., 2009; Burkett, 2011; Porta and Bankes, 2011) or when comparing the scope of Arctic EA research to that outside the Arctic. Second, we consolidated the research recommendations identified in the range of literature we reviewed.

We then used a questionnaire survey to seek the views of 10 EA scholars and other experts engaged in EA research and development in the Arctic. We asked what they saw as the major gaps in EA research and EA-related knowledge in the Arctic that will require significant attention over the next decade. The 10 individuals were drawn from our own research networks or recommended to us by colleagues and other research participants (a "snowball" technique). All are well published in the field, and they constitute an elite survey group. Although the 10 contributors were from four different countries, they were asked to comment on EA research in the Arctic more broadly and not on jurisdictionspecific matters or regulatory issues. This sample of experts was not intended to represent specific EA jurisdictions. Our objective was to seek guidance in validating Arcticwide EA research gaps and priorities identified from our review of the literature and to determine whether additional research needs that we did not capture should be included. The results of course reflect the knowledge and experience of those surveyed. The survey was conducted by email and participant confidentiality was assured.

\section{RESULTS}

Many issues addressed in the scholarly literature on EA in the Arctic appear similar to those addressed in EA 
research outside the Arctic regions. Our review of the literature identified 194 research papers with a focus on some aspect of EA in the Arctic. From these, we identified eight major research themes, each with various subthemes (Table 1). The themes identified were influenced by the scope of our review and are a product of our analysis of the literature; thus, they focus on research about formal EA. The themes are not necessarily independent; for example, some recent research focused on transboundary EA is set within the context of strategic EA, and project-based EA is likely to have multi-jurisdictional impacts. In such cases, we examined the paper's objectives and recommendations and assigned each paper to the theme that we considered to best represent its content.

Two of the eight research themes we identified, (1) collaboration and participation and (2) cultural, social, and health impacts, were the main focus in about $38 \%$ of the papers that we surveyed. This result was not surprising; such topics have long been of interest and importance in the Arctic. Research on traditional knowledge and community participation in the EA process and on the assessment of social, health, and cultural impacts were major sub-themes. Regional and strategic EA were the theme of $15 \%$ of the papers. Much of the research under this theme was from the past five to eight years, and not surprisingly focused on emerging Arctic energy resource development and the assessment of cumulative environmental effects. The remaining $47 \%$ of the literature addressed various aspects of the procedural effectiveness of EA, the influence of EA on decision making, transboundary assessment and international EA laws and regulations, negotiated agreements (e.g., impact and benefit agreements and environmental agreements), and specific tools and techniques that support EA application.

\section{RESEARCH GAPS AND PRIORITIES}

To advance the effectiveness of EA and ensure its relevance to Arctic communities and stakeholders, a range of research gaps, spanning several disciplines, need to be addressed. Some of these reflect enduring concerns about the efficacy of EA, while others reflect emerging issues and concerns in Arctic EA. The research gaps are based on our analysis of the literature and key informant feedback. We limit our focus to seven key gaps and the opportunities that are most closely linked to ensuring effective application and use of EA for Arctic communities and ecosystems (Table 2).

\section{Understanding Expectations about EA}

Despite the extensive scope of research on EA in the Arctic, we found only limited research that addressed community and stakeholder expectations about EA. Environmental assessment has come under much criticism in recent years, and a good portion of this negative commentary has centered on the role of EA in addressing community and social expectations and needs. However, Fuggle (2005) warns that EA is not a "magic bullet" that can resolve all environmental and socio-economic issues. Part of the challenge to understanding the efficacy of EA is that the underlying purpose of EA is still much debated. Cashmore (2004) argues that EA can be perceived as a series of nebulous models, operating along a broad spectrum of philosophies and values concerning the role of science in EA. At one end of this spectrum is the belief that the scientific method provides the basis for EA theory and practice; at the other end is the belief that EA is a civic science designed to empower communities, promote social justice, and help realize community self-governance (Bond et al., 2014).

On the basis of the Swedish experience, HildingRydevik (2006:25) argues that what constitutes "effective" EA can be "...viewed from the various and differing perspectives of the many actor groups that are a part of the EA system and its processes-legislators, proponents, competent authorities, NGOs, etc." Different actors have different roles in and aspirations for EA in the Arctic, and they may view effective EA according to their role in and influence on the decisions that emerge. Kaltenborn (1998) argues that EA processes often do not consider the importance of local context. Sasvari (2012), for example, reporting on recent EA experiences of Saami reindeer-herding communities in northern Sweden and their interactions with developers, concludes that policies continue to conflict with Saami perceptions and knowledge. In reviewing the EA process for the BHP diamond mine in Canada's Northwest Territories, O'Reilly (1996) and CARC (1996) argued that the process was neither rigorous, nor comprehensive, nor fair; whereas Kwiatkowski and Ooi (2003) characterized the EA as an example of integrated assessment that considered social, cultural, health, and environmental impacts and resulted in a project that coordinated the concerns of all stakeholders in support of sustainable development.

In reviews of EA in the western Arctic offshore energy sector, Ketilson (2011) and Noble et al. (2013) identified a range of expectations about EA, specifically strategic EA, and report a diversity of views about what EA can and should deliver in the western Arctic, and to whom. Similarly, in Greenland's offshore oil sector, Olsen and Hansen (2014) report a diversity of expectations concerning what EA should deliver versus what it can deliver regarding effective participation. The authors report that the varying interests of stakeholders create different expectations, and these diverse expectations are not always fulfilled. Olsen and Hansen (2014) explain that industry often approaches EA, particularly through public engagement, as a means to manage expectations and achieve a social license to operate; environmental organizations view the process as a means to influence decisions; while local communities view the process as a means to understand a project, prepare for its impacts, and better capture potential economic opportunities. Both the requirements for and the practice of EA vary considerably across the Arctic jurisdictions, but there has been limited effort amongst the EA research 
TABLE 1. Current Arctic EA research themes and sub-themes.

\begin{tabular}{|c|c|c|}
\hline EA research theme & Sub-themes & Examples \\
\hline Collaboration and participation & $\begin{array}{l}\text { Collaborative EA; } \\
\text { Learning; } \\
\text { Participation and deliberative democracy; } \\
\text { Community participation and negotiation; } \\
\text { Traditional knowledge; } \\
\text { Interactive planning; } \\
\text { Local capacity for engagement; } \\
\text { Conflict and early consultation; } \\
\text { Knowledge mobilization; } \\
\text { Social equity, empowerment and exclusion. }\end{array}$ & $\begin{array}{l}\text { Wismer, 1996; } \\
\text { Huttunen, 1999; } \\
\text { Lidskog and Soneryd, 2000; } \\
\text { Saarikoski, 2000; Couch, 2002; } \\
\text { Armitage, 2005; Hildén, 2005; } \\
\text { Meschtyb et al., 2005; } \\
\text { Lajoie and Bouchard 2006; } \\
\text { Fitzpatrick et al., 2008; } \\
\text { Koivurova, 2008; } \\
\text { Sasvari, 2012. }\end{array}$ \\
\hline
\end{tabular}

Cultural, social, and health impacts

Regional environmental assessment

Procedural effectiveness

Environmental assessment and decision making

Transboundary assessment and international law and policy

Negotiated agreements evaluation tools and techniques
Integrating spiritual and cultural issues in EA;

Social impact follow-up and monitoring;

Health integration in EA;

Mitigating health impacts;

Determinants of health;

Scope of health considerations in EA;

Planning for community impacts of mega-projects;

Strengthening social impact assessment;

Consideration of local socio-cultural context.

Cumulative environmental effects;

Opportunities for and constraints on strategic EA in the Arctic;

Strategic EA for offshore energy;

Need to upstream EA to the strategic level;

Regional strategic EA for coordinated marine spatial planning;

Strategic EA for marine environmental sustainability;

Identifying priorities for Arctic development;

Regional assessment for sensitive wildlife.

Adequacy of EA scoping;

Weight of evidence of cultural impacts;

Inter-cultural communication;

Problems of non-binding decisions;

Adaptive approaches;

Limitations to highly systematic decision processes;

Mitigation effectiveness;

Follow-up and monitoring;

Timing of application;

Institutional evolution;

Regulatory complexity.

Legality versus legitimacy;

Use of EA information in decision process;

Action-forcing mechanisms for implementing EA results;

Securing knowledge versus influencing decisions;

Influence of community consultation on decisions made.

Strategies for Arctic environmental protection;

Existence versus uptake of Arctic guidelines for EA;

Consultation challenges regarding transboundary issues;

Challenges due to differing approaches to and provisions for EA across the Arctic

Strategic EA to address transboundary impacts;

Disregard for Arctic ecosystems in jurisdictional EA processes.

Rationale for impact and benefit agreements;

Scope and function of impact and benefit agreements;

Environmental agreements and the regulatory process;

Aboriginal engagement in negotiated agreements;

Community-based monitoring under environmental agreements;

Link between environmental agreements and environmental assessment.

Scenario analysis;

Remote sensing for biodiversity assessment;

Geographic Information Systems application;

Technical tools for monitoring support;

Wildlife assessment.
Juslén, 1995; Kaltenborn, 1998; Gagnon, 2003; Kwiatkowski and Ooi, 2003; National Research Council, 2003; Storey and Hamilton, 2003; Meschtyb et al. 2005; Noble and Bronson, 2005 , 2006; Wernham, 2007; Erikstad et al., 2008; MVEIRB, 2008; Ehrlich, 2010; Sasvari, 2012.

Bruhn-Tysk and Eklund, 2002; Newton et al., 2002; Johnson et al., 2005; Solodyankina and Koeppel, 2009; Hansen and Kørnøv, 2010; Orenstein et al., 2010; Doelle et al., 2012; Elvin and Fraser, 2012; Fidler and Noble, 2012, 2013a, b; Noble et al., 2013.

CARC, 1996; O’Reilly, 1996; Mulvihill and Baker, 2001; Couch, 2002; Nellemann and Vistnes, 2003; Cherp and Golubeva, 2004; Haefele and Cliffe-Phillips, 2004; Ovind and Sneve, 2004; Ross, 2004;

McCrank, 2008; MVEIRB, 2008; Voutier et al., 2008; Ehrlich, 2010; Jalava et al., 2010.

Hokkanen, 2001; Haefele and Cliffe-Phillips, 2004; Hildén and Jalonen, 2005; Ehrlich, 2010; Hansen, 2011; Noble and Birk, 2011; Pölönen et al., 2011; Sasvari, 2012.

Arctic Environment Protection Strategy, 1997; Huebert, 1998; Koivurova, 2002, 2008; Brubaker and Ragner, 2010; European Union, 2010; Azcarate et al., 2011.

Sosa and Keenan, 2001; Klein et al., 2004; Fidler and Hitch, 2007

Galbraith et al., 2007;

O'Faircheallaigh, 2007;

Prno and Bradshaw, 2008; Knotsch and Warda, 2009; Fidler, 2010; Noble and Birk, 2011; Noble and Fidler, 2011.

Newton et al., 2002; Rigina, 2002.

Johnson et al., 2005;

Vlassova, 2006;

Kumpula et al., 2011. 
TABLE 2. A synthesis of underexplored themes or gaps in northern EA research and important research questions to address these gaps.

\begin{tabular}{|c|c|}
\hline Community and stakeholder expectations about EA & $\begin{array}{l}\text { a. What do Arctic communities and stakeholders expect of EA? } \\
\text { b. Is EA the right mechanism to meet these expectations? }\end{array}$ \\
\hline Efficiency and responsiveness & $\begin{array}{l}\text { a. As a process is EA sufficiently expeditious, flexible, and responsive to communities' and } \\
\text { proponent's needs in the context of a rapidly changing Arctic economic and biophysical } \\
\text { environment? } \\
\text { b. What reforms are needed to ensure that the processes of EA are sufficiently expeditious, } \\
\text { flexible, and responsive to communities' and proponent's needs without compromising its } \\
\text { effectiveness? }\end{array}$ \\
\hline Impact and influence of EA & $\begin{array}{l}\text { a. What influence has EA had on development decisions across the Arctic? } \\
\text { b. What lessons can be learned from the decades of EA application to resource megaprojects } \\
\text { across the Arctic? }\end{array}$ \\
\hline Capacity for meaningful engagement in EA & $\begin{array}{l}\text { a. Has past engagement in EA facilitated learning and capacity building in Arctic } \\
\text { communities? } \\
\text { b. What is the current capacity of Arctic communities and Aboriginal organizations to be } \\
\text { meaningfully engaged in EA, or to use EA as a planning and decision-making tool? } \\
\text { c. Given the expected increase in development applications in an ice-free Arctic, what are the } \\
\text { capacity-building requirements to ensure sustained and meaningful engagement in EA? } \\
\text { d. What institutional or process reforms are needed to ensure more effective engagement in EA } \\
\text { in the face of limited resources and under the time constraints of evolving EA processes? }\end{array}$ \\
\hline Strengthening EA through land-use planning and science & $\begin{array}{l}\text { a. Are current regional planning, science, and monitoring programs in the Arctic responsive to } \\
\text { the regulatory and broad governance needs of EA? } \\
\text { b. What are the opportunities and mechanisms to improve EA practice through better } \\
\text { integration with regional planning? } \\
\text { c. How can current Arctic science and monitoring programs be better integrated into EA } \\
\text { practices and decision making? }\end{array}$ \\
\hline Applied regional and strategic EA & $\begin{array}{l}\text { a. As part of developing future-oriented planning and assessment processes, what frameworks } \\
\text { and methods are needed to support EA application at regional or sub-regional scales? } \\
\text { b. What lessons, opportunities, and institutional requirements will aid in scaling up regional } \\
\text { EA to Arctic planning regions and transboundary eco-regions? }\end{array}$ \\
\hline
\end{tabular}

community to fully understand the diversity of community and stakeholder expectations about EA.

\section{Process Efficiency and Responsiveness}

The Arctic Monitoring and Assessment Programme (AMAP, 2007) recommended that EA and related planning tools be "rigorously applied" in the Arctic, but also emphasized that such tools must be "streamlined to increase their relevance and usefulness" (AMAP, 2007:viii). Recent literature on EA effectiveness has tended to focus on making the process less cumbersome and more efficient (Morgan, 2012; Bond et al., 2014). Evaluations of Arctic EA have largely reflected the perspective of industry or regulators and focused almost exclusively on process or regulatory efficiency (e.g., Harrison, 2006; McCrank, 2008; Voutier et al., 2008). In Russia, for example, von Ritter and Tsirkunov (2003) report that EA is often viewed by project proponents as an extra burden in the development and licensing process offering limited added value for their project. This view is hardly limited to Russia. In Canada's Arctic, Voutier et al. (2008:105) have suggested that EA is becoming increasingly complex and that the "regulatory regime will undermine the attractiveness" of the Arctic to industry investors. More recently, in Iceland, a 2014 OECD performance review describes the EA process as complex and slow and recommends, as a step towards "green growth," further streamlining of the EA process to reduce administrative costs and delay (OECD, 2014). Much less attention has been given to Arctic community views of the EA process, including its complexity and responsiveness to concerns about development in a rapidly changing Arctic environment, or to whether expediting an EA process to accommodate a proponent's needs and regulatory efficiencies necessarily compromises the effectiveness of that process.

\section{Impact and Influence}

Efficiency is a valid concern, particularly for development proponents, but more attention needs to be given to understanding the impact of EA on decisions about development in the Arctic and the contribution of EA to improved environmental management. There has been some limited reporting on the impact of Arctic EA on decision outcomes. Ehrlich (2010), for example, addressed the "weighing of 
evidence" with respect to the assessment of spiritual issues and the role it played in the rejection of three projects and conditional approval of another in Canada's Arctic. However, Hansen (2011) argues that apart from securing traditional environmental knowledge, there is little evidence that EA in the Arctic has influenced decision making.

In the Finnish context, Hildén and Jalonen (2005) report limited influence of EA on decision-making and development choices, and Pölönen (2006) concludes that both the EU Directive and the Finnish EA legislation fail to guarantee the successful transfer of assessment results to decision making. Hokkanen (2001) reports that a significant amount of raw information is generated through Finnish EA, but there is insufficient time to use the resulting knowledge; and Jalava et al. (2010) report that Finnish EAs suffer from irrelevant information reported in a lengthy way, which may serve to confuse and obscure essential points.

Impact and influence have been long-standing issues under Russia's EA system (Cherp and Golubeva, 2012). Von Ritter and Tsirkunov (2003), for example, found that the EA system in Russia has had limited impact on project design, aside from cases of highly visible and internationally financed projects. Reported among the reasons for the limited influence is the poor quality of baseline environmental data, the limited capacities of EA regions to implement regulatory requirements, and the late preparation of EAs - often after important project decisions have been made. While these reasons may reflect institutional and political challenges within the Russian context, similar problems may be observed in other Arctic jurisdictions (e.g., MVEIRB, 2005; McCrank, 2008; Olsen and Hansen, 2014).

We agree with Mulvihill and Baker (2001) that too little information has been shared about EAs and their outcomes in the North. Thus new assessments often cannot benefit from the lessons learned in decades of applying EA to resource mega-projects across the Arctic.

\section{Capacity for Meaningful Engagement in EA}

The increasing recognition of the need for EAs in the Arctic to recognize and integrate traditional knowledge has increased the expectations for industry to ensure early and ongoing community engagement (Saarikoski, 2000; Armitage, 2005; Meschtyb et al., 2005; Fitzpatrick et al., 2008). In his analysis of the Sierilä hydropower station in northern Finland, for example, Huttunen (1999:34) reported that community engagement in the EA process increased mutual learning and understanding, as well the degree of interactive planning, resulting in "a significant awakening to their own empowerment and self-management" among community members. At the same time, Huttunen cautioned that communities often lack the capacity to participate effectively in the EA process. Capacity concerns were similarly raised by stakeholders at the 2011 Alaska Forum on the Environment, reporting to the U.S. Environmental Protection Agency the need for Arctic communities not only to see the benefits of their engagement in EA, but also to be provided with the resources needed to ensure meaningful engagement (IWG, 2011).

Growing requirements for and expectations of consultation with Arctic communities before, during, and after the EA process, combined with increasing numbers of EA applications for Arctic development, are raising concerns about the capacity of Arctic communities to become meaningfully engaged in EA processes. In their review of marine planning, assessment, and science programs in Canada's western Arctic, for example, Fidler and Noble (2013a) identified local capacity and resources as constraints on meaningful participation in the EA process. The report of the Mackenzie Valley Environmental Impact Review Board's 2008 EIA Practitioners' Workshop (MVEIRB, 2008) similarly identified the lack of capacity as an ongoing concern in Arctic EA, noting specifically community concerns about the constant struggle to retain their capacity to participate in EA and the increasing workload of Aboriginal groups to coordinate EAs with land users, elders, and their chief and council. McCrank (2008) also identified limited institutional and human resource capacity of Aboriginal organizations as potentially hindering their ability to participate in the EA process and to document and interpret traditional knowledge to assist in decision making.

Regardless of advancements, not all regions provide an opportunity for engagement in EA processes. In Russia, for example, public participation varies across regions depending on the openness of the respective regional authorities. A 2006 OECD review of environmental policy and regulation in Russia described the EA system as technocratic, focused on verifying project compliance with existing laws and regulations, with limited opportunity for public participation until the very late stages of the process, when participation is best described as non-government organization activism as opposed to meaningful engagement (OECD, 2006). In Canada, the National Energy Board has implemented an onerous process of approving who is allowed to participate in hearing processes, restricting issues to be addressed and discussed during its deliberations.

Given the enduring concerns over engagement in EA, combined with the anticipated growth in EA applications for Arctic development, there is a need to examine how to facilitate capacity building in Arctic communities that will permit meaningful engagement in EA, as well as the institutional or process reforms necessary to ensure that such engagement occurs.

\section{Opportunities and Mechanisms to Link Strategic Initiatives with EA}

Not all issues can be appropriately assessed, understood, or managed at the scale of project-based EA. Increasingly, scholars, communities, and environmental organizations are lobbying for more regional and strategic approaches to EA in the Arctic (Cherp and Golubeva, 2004; WWF, 2005; Voutier et al., 2008; Doelle et al., 2012; Fidler and Noble, 
2012; Noble et al., 2013). Specifically, there is a recognized need for EA to be more proactive in its approach to planning for future development and to better assess cumulative environmental effects, including climate-change and transboundary effects. The challenge, however, is that although many planning, science, and assessment programs are ongoing in the Arctic, it remains uclear how these programs contribute to better EA, and vice versa.

In the Canadian Arctic, for example, regional initiatives such as the Integrated Oceans Management Plan (IOMP), the Beaufort Regional Environmental Assessment (BREA), the Integrated Regional Impact Studies (IRIS), the Cumulative Impact Monitoring Program (CIMP), and various land-use plans address issues that may be relevant to EA; however, the challenge is to determine how the processes and data and knowledge generated are best translated and used to inform and influence regulatory EA processes and decisions (Fidler and Noble, 2013a). There is also an assumption that these processes, and the data and information generated, are useful to EA decisions. Concerning CIMP, for example, the MVEIRB (2005:7) reports: “...it is unclear to the MVEIRB what information is being collected through CIMP.... and how this information can be used in the EA process."

This relationship between regional and strategic initiatives and EA, described in the EA literature (João, 2005; Fischer, 2006) as "tiering," assumes that regional or higherlevel initiatives (e.g., planning processes, regional studies, and monitoring programs) are intended to influence or provide strategic direction to project-based EA. Lessons reported from the Norwegian experience in the Barents Sea have shown some indicators of successful tiering (see Fidler and Noble, 2012). In 2006, the Norwegian parliament introduced its Integrated Management Plan, a process designed to capture all sectors in the offshore environment, assess total impact, and identify knowledge gaps and conflict areas so as to provide an overview of where and under what conditions offshore activity should occur. Although the Integrated Management Plan provides an opportunity for project proponents to demonstrate compliance with higher-level planning goals and priorities, the Barents Sea Integrated Management Plan is not tiered toward individual energy field developments and is not necessary for the approval of new developments.

Discovering how best to implement such tiered arrangements in the Arctic remains a significant challenge in practice. Research is required to determine the value added to Arctic EA by such high-level regional policy, planning, and science initiatives, as well as the governance and institutional opportunities needed to better link these initiatives with downstream project-based EA decisions (Fidler and Noble, 2013b).

\section{Applied Research to Demonstrate Regional Strategic EA}

In 2008, the Beaufort Sea Strategic Regional Plan of Action (BSStRPA, 2008) identified the need for a coordinated and strategic approach to EA in the Beaufort region of Canada's western Arctic (BSStRPA, 2008). The federal response was BREA, a four-year research project designed to collect data on specific issues related to offshore oil and gas development and to identify and fill gaps in baseline environmental data related to offshore activities and the marine environment for the purpose of supporting project-specific EAs. It is hoped that BREA will prove valuable in these regards, but the strategic need to identify priorities for sustainable development in the Arctic (see Newton et al., 2002), a fundamental feature of regional strategic EA, is missing from the BREA process (Fidler and Noble, 2013b).

Work has been done to advance the understanding of regional strategic EA and produce a generic framework for it (e.g., CCME, 2009; Gunn and Noble, 2009), and there is a growing volume of research on regional strategic EA opportunities in the Arctic, particularly in the marine environments of Norway and Arctic Canada (e.g., Kinn, 1999; Doelle et al., 2012; Fidler and Noble, 2013b). In Norway, for example, regional strategic EA is described as an effective process for determining how to move forward in terms of planning for offshore development and, in the context of offshore hydrocarbon development, where future leasing could occur (Fidler and Noble, 2012). However, Ketilson (2011), in her review of regional strategic EA in Canada's western Arctic, identified reservations among communities, regulators, and industry about regional strategic EA because its benefits are unproven. The EA scholarly community has approached the need for and potential role of regional and strategic EA in the Arctic; but further applied research is needed to pilot-test regional and strategic EA applications, specifically applications that involve prospective or future-based assessment, and to learn from those applications.

\section{Adapting EA to Climate Change}

It would be difficult to overstate the importance of climate change to the stability and resilience of Arctic environments, societies, and economies. One perverse outcome of environmental change may be the increased accessibility of energy and other resources across Arctic regions. The MVEIRB (2005:7) notes that climate change "has not yet featured prominently in any EA, with the exception of the Mackenzie Gas Project," but the Review Board "anticipates that climate change issues will play an increasing role in future assessments." Notwithstanding the considerable legacy of research on Arctic climate change, we found very little Arctic EA research focused specifically on climate change and how, through EA, the impacts of climate change on Arctic development potential and the impacts of Arctic development on climate change can be best addressed. Although recent literature has focused on climate change mitigation in EA (Burdge, 2008; Byer et al., 2012), specifically project-based assessment and mitigation of greenhouse gas emissions (Sok et al., 2011; Ohsawa and 
Duinker, 2014), the implications for the EA process, and for those Arctic development sectors subject to EA, remain unexplored. Climate change will inevitably impose new demands on EA, but EA may also function as an essential tool for addressing the challenges to new and expanded development under changing climatic conditions.

\section{CONCLUSION}

This paper has examined the current state of research on Arctic EA and identified gaps in research that should be addressed in order to advance the effectiveness of EA in the Arctic, enhance its relevance to Arctic communities, and help address issues unique to resource development and environmental protection across this global region. The study identified seven priority research themes for Arctic EA. While these will not be the only areas that need research, and there are diverse interpretations about what works, what is not working, and what needs to be done to improve EA practice across the Arctic, the gaps and priorities outlined in this study reflect a systematic and deliberative process designed to identify and prioritize knowledge gaps.

Four enduring issues, while evident in the survey responses and apparent in some sources (MVEIRB, 2005; Noble and Fidler, 2011; Doelle et al., 2012), were not treated as unique gaps in Arctic EA research. They are persistent needs in EA practice, regardless of political-economic context or location; but they can pose unique challenges for Arctic settings. The first is the development of more extensive and regionally responsive socio-economic indicators to support EA practice. The MVEIRB (2005), for example, reports the lack of baseline information on socio-economic conditions in the Arctic as an ongoing concern. Baseline conditions will also shift with the advance of climate change impacts requiring flexible and adaptive approaches to data collection and related inventories. One specific need is to identify indicators for assessing socio-economic conditions that are not only responsive to regional change, but also useful for predicting and evaluating the impacts of local resource development projects. Drawing on social EA research in Finland's mining sector, Suopajärvi (2013) argues that such indicators should be not only "hard" or "quantitative," but also qualitative, value-based, and sometimes interpretive in approach. Suopajärvi further argues that greater attention needs to be given to open discussion about the theoretical and methodological choices that inform the selection of social indicators used in EA.

Second, there is a need to examine closely the operational and administrative relationships between privately negotiated agreements (e.g., impact benefit agreements) and EA regulatory processes. Such agreements are commonplace in some Arctic regions, particularly in Canada's Northwest Territories (see www.impactandbenefit. com), and have become part of the reality of business practices in the mining sector (Veiga et al., 2001). Greenland has adopted a different approach to impact benefit agreements, whereby negotiated agreements are part of the formal requirements for Strategic Social Impact Assessments. Such agreements are arranged between the proponents, affected municipalities, and the national government and are within the realm of public law. Comparative analyses of private versus public approaches to negotiated agreements may provide a better understanding of the extent to which the confidential nature of negotiated agreements either complements or undermines the public EA process (see Noble and Fidler, 2011).

Third, although guidelines for EA were adopted in 1997 under the Arctic Environmental Protection Strategy for cooperation between the eight Arctic states, these guidelines have not been fully incorporated into national EA systems (Koivurova, 2008). The coordination of EA roles and responsibilities between jurisdictions to address transboundary impacts has proven difficult even within national EA systems (Fitzpatrick and Sinclair, 2009), but these challenges are greater when dealing with transboundary impacts that involve multiple national EA systems. Although there has been some experience with transboundary EA cooperation in the Arctic (see Koivurova, 2008), research is needed to explore the institutional, policy, and legal options and opportunities for strengthening international Arctic EA coordination.

Finally, there is a need to examine the implications of recent changes to EA processes, regulations, and legislation. In Canada, for example, the introduction of the Canadian Environmental Assessment Act in 2012 changed the role of the federal government in EA and has prompted some critical analysis (Doelle, 2012; Gibson, 2012). But other regulatory changes may occur across the Arctic nations over the next decade that will likely affect the priority areas identified in this gap analysis, requiring further investigation.

This paper provides an outline of key areas of research and knowledge needs for EA in the Arctic. These needs reflect the changing nature of Arctic regions (socially and environmentally), the transitional qualities of EA regulation and application, and the realization that Arctic regions face increasingly significant development pressures. Environmental assessment should play a key role in planning for the impacts of environmental, social, and economic change and in developing responses that will allow Arctic communities to best respond to new opportunities and the substantial transformations that are inevitable.

\section{ACKNOWLEDGEMENTS}

This paper was based on research completed for the Resources and Sustainable Development in the Arctic program, an initiative funded by the Social Sciences and Humanities Research Council of Canada. We wish to acknowledge our key informants for contributing their time and expertise to the gap analysis. 


\section{REFERENCES}

AMAP (Arctic Monitoring and Assessment Programme). 2007. Arctic oil and gas 2007. Oslo, Norway: AMAP.

Appiah-Opoku, S. 2001. Environmental impact assessment in developing countries: The case of Ghana. Environmental Impact Assessment Review 21(1):59-71.

http://dx.doi.org/10.1016/S0195-9255(00)00063-9

Arctic Council. 1997. Alta declaration on the strategy for the protection of the Arctic environment. Alta, Norway: Arctic Council.

Arctic Environment Protection Strategy. 1997. Guidelines for environmental impact assessment (EIA) in the Arctic: Sustainable development and utilization. Helsinki: Finnish Ministry of the Environment. 50 p.

Armitage, D.R. 2005. Collaborative environmental assessment in the Northwest Territories, Canada. Environmental Impact Assessment Review 25(3):239-258.

http://dx.doi.org/10.1016/j.eiar.2004.06.012

Azcarate, J., Balfors, B., Destouni, G., and Bring, A. 2011. Shaping a sustainability strategy for the Arctic. 31st Annual Conference of the International Association for Impact Assessment, 28 May-4 June 2011, Puebla, Mexico. 5 p.

Baykoucheva, S. 2010. Selecting a database for drug literature retrieval: A comparison of MEDLINE, Scopus, and Web of Science. Sciences \& Technology Libraries 29(4):276-288. http://dx.doi.org/10.1080/0194262X.2010.522946

Berger, T.R. 1977. Northern frontier, northern homeland: The report of the Mackenzie Valley Pipeline Inquiry. Ottawa: Environment Canada.

Bond, A., Pope, J., Morrison-Saunders, A., Retief, F., and Gunn, J.A.E. 2014. Impact assessment: Eroding benefits through streamlining? Environmental Impact Assessment Review 45:46-53.

http://dx.doi.org/10.1016/j.eiar.2013.12.002

Boyden, A. 2007. Environmental assessment under threat. IAIA Newsletter 19(1):4. Fargo, North Dakota: International Association for Impact Assessment.

Brubaker, D.R., and Ragner, C.L. 2010. A review of the International Northern Sea Route Program (INSROP) - 10 years on. Polar Geography 33(1-2):15-38.

http://dx.doi.org/10.1080/1088937X.2010.493308

Bruhn-Tysk, S., and Eklund, M. 2002. Environmental impact assessment - a tool for sustainable development?: A case study of biofuelled energy plants in Sweden. Environmental Impact Assessment Review 22(2):129-144. http://dx.doi.org/10.1016/S0195-9255(01)00104-4

BSStRPA (Beaufort Sea Strategic Regional Plan of Action). 2008. Presentation to the Beaufort Basin Workshop, 30 January 2008, Ottawa, Ontario.

http://ww w.beaufortseapartnership.ca/documents/BB Strategic Plan.pdf

Burdge, R.J. 2008. The focus of impact assessment (and IAIA) must now shift to climate change! Environmental Impact Assessment Review 28(8):618-622.

http://dx.doi.org/10.1016/j.eiar.2008.03.001
Burkett, V. 2011. Global climate change implications for coastal and offshore oil and gas development. Energy Policy 39(12):7719-7725. http://dx.doi.org/10.1016/j.enpol.2011.09.016

Byer, P., Cestti, R., Croal, P., Fisher, W., Hazell, S., Kolhoff, A., and Kørnøv, L. 2012. Climate change in impact assessment: International best practice principles. Special Publication Series No. 8. Fargo, North Dakota: International Association for Impact Assessment.

CARC (Canadian Arctic Resources Committee). 1996. Critique of the BHP environmental assessment: Purpose, structure, and process. Northern Perspectives 24:1-4.

Cashmore, M. 2004. The role of science in environmental impact assessment: Process and procedure versus purpose in the development of theory. Environmental Impact Assessment Review 24(4):403-426.

http://dx.doi.org/10.1016/j.eiar.2003.12.002

Cashmore, M.A., Cobb, D., Bond, A., and Gwilliam, R. 2004. Enhancing the 'substantive' effectiveness of EIA: A case for reform of the EIA research agenda? In: Hilding-Rydevik, T., and Theodórsdóttir, Á.H., eds. Planning for sustainable development - the practice and potential of environmental assessment. Proceedings from the $5^{\text {th }}$ Nordic Environmental Assessment Conference, 25-26 August 2003, Reykjavik, Iceland. Nordregio Report 2004:2. Stockholm: Nordregio. $157-181$.

CCME (Canadian Council of Ministers of the Environment). 2009. Regional strategic environmental assessment in Canada: Principles and guidance. Winnipeg, Manitoba: CCME.

Chanchitpricha, C., and Bond, A. 2013. Conceptualizing the effectiveness of impact assessment processes. Environmental Impact Assessment Review 43:65-72. http://dx.doi.org/10.1016/j.eiar.2013.05.006

Che, X., English, A., Lu, J., and Chen, Y.D. 2011. Improving the effectiveness of planning EIA (PEIA) in China: Integrating planning and assessment during the preparation of Shenzhen's master urban plan. Environmental Impact Assessment Review 31(6):561-571.

http://dx.doi.org/10.1016/j.eiar.2010.12.003

Cherp, A., and Golubeva, S. 2004. Environmental assessment in the Russian Federation: Evolution through capacity building. Impact Assessment and Project Appraisal 22(2):121 - 130. http://dx.doi.org/10.3152/147154604781766030

Colclough, C., and Perera, O. 2013. Sustainable development in Greenland: Perspectives from a preliminary stakeholder consultation. Winnipeg, Manitoba: International Institute for Sustainable Development.

Couch, W.J. 2002. Strategic resolution of policy, environmental and socio-economic impacts in Canadian Arctic diamond mining: BHP's NWT diamond project. Impact Assessment and Project Appraisal 20(4):265-278. http://dx.doi.org/10.3152/147154602781766564

Creswell, J.W. 2013. Qualitative inquiry and research design: Choosing among five approaches, $3^{\text {rd }}$ ed. Thousand Oaks, California: Sage. 
Doelle, M. 2012. CEAA 2012: The end of federal EA as we know it? Journal of Environmental Law and Practice 24(1). 17 p. http://dx.doi.org/10.2139/ssrn.2104336

Doelle, M., Bankes, N., and Porta, L. 2012. Using strategic environmental assessments to guide oil and gas exploration decisions in the Beaufort Sea: Lessons learned from Atlantic Canada. Occasional Paper 39. Calgary, Alberta: Canadian Institute of Resources Law. 27 p.

Ehrlich, A. 2010. Cumulative cultural effects and reasonably foreseeable future developments in the Upper Thelon Basin, Canada. Impact Assessment and Project Appraisal 28(4):279-286. http://dx.doi.org/10.3152/146155110X12838715793084

Elvin, S.S., and Fraser, G.S. 2012. Advancing a national strategic environmental assessment for the Canadian offshore oil and gas industry with special emphasis on cumulative effects. Journal of Environmental Assessment Policy and Management 14(3): $1250015.37 \mathrm{p}$.

http://dx.doi.org/10.1142/S1464333212500159

Erikstad, L., Lindblom, I., Jerpåsen, G., Hanssen, M.A., Bekkby, T., Stabbetorp, O., and Bakkestuen, V. 2008. Environmental value assessment in a multidisciplinary EIA setting. Environmental Impact Assessment Review 28(2-3):131 - 143. http://dx.doi.org/10.1016/j.eiar.2007.03.005

European Union. 2010. EU Arctic footprint and policy assessment: Final report. Berlin: Ecologic Institute.

http://arctic-footprint.eu/sites/default/files/AFPA_Final_ Report.pdf

Fidler, C. 2010. Increasing the sustainability of a resource development: Aboriginal engagement and negotiated agreements. Environment, Development and Sustainability 12(2):233-244.

http://dx.doi.org/10.1007/s10668-009-9191-6

Fidler, C., and Hitch, M. 2007. Impact and benefit agreements: A contentious issue for environmental and Aboriginal justice. Environments Journal 35(2):49-69.

Fidler, C., and Noble, B.F. 2012. Advancing strategic environmental assessment in the offshore oil and gas sector: Lessons from Norway, Canada, and the United Kingdom. Environmental Impact Assessment Review 34:12-21.

http://dx.doi.org/10.1016/j.eiar.2011.11.004

- 2013a. Stakeholder perceptions of current planning, assessment and science initiatives in Canada's Beaufort Sea. Arctic 66(2):179-190.

http://dx.doi.org/10.14430/arctic4289

—. 2013b. Advancing regional strategic environmental assessment in Canada's western Arctic: Implementation opportunities and challenges. Journal of Environmental Assessment Policy and Management 15(1): 1350007. 27 p. http://dx.doi.org/10.1142/S1464333213500075

Fischer, T.B. 2006. Linkages between SEA and other assessment or planning tools. Journal of Environmental Assessment Policy and Management 8(4):495-504.

Fitzpatrick, P., and Sinclair, J. 2009. Multi-jurisdictional environmental assessment. In: Hanna, K.S., ed. Environmental impact assessment: Practice and participation, $2^{\text {nd }}$ ed. Don Mills, Ontario: Oxford University Press. 173-192.
Fitzpatrick, P., Sinclair, A.J., and Mitchell, B. 2008. Environmental impact assessment under the Mackenzie Valley Resource Management Act: Deliberative democracy in Canada's North? Environmental Management 42(1):1-18.

http://dx.doi.org/10.1007/s00267-008-9098-2

Fuggle, R. 2005. Have impact assessments passed their 'sell by' date? International Association for Impact Assessment Newsletter 16(1):1, 6.

Gagnon, C. 2003. Methodology of social impact follow-up modeling: The case study of a new aluminium smelter in Canada (Alma, Alcan). In: Rasmussen, R.O., and Koroleva, N.E., eds. Social and environmental impacts in the North: Methods in evaluation of socio-economic and environmental consequences of mining and energy production in the Arctic and sub-Arctic. Dordrecht, Netherlands: Kluwer Academic Publishers. 479-489.

Galbraith, L., Bradshaw, B., and Rutherford, M.B. 2007. Towards a new supraregulatory approach to environmental assessment in northern Canada. Impact Assessment and Project Appraisal 25(1):27-41. http://dx.doi.org/10.3152/146155107X190596

Gibson, R.B. 2012. In full retreat: The Canadian government's new environmental assessment law undoes decades of progress. Impact Assessment and Project Appraisal 30(3):179-188. http://dx.doi.org/10.1080/14615517.2012.720417

Gibson, R., and Hanna, K. 2009. The evolution of federal environmental assessment in Canada. In: Hanna, K., ed. Environmental impact assessment practice and participation, 2nd ed. Don Mills, Ontario: Oxford University Press. 18-36.

Gunn, J.H., and Noble, B.F. 2009. A conceptual basis and methodological framework for regional strategic environmental assessment (R-SEA). Impact Assessment and Project Appraisal 27(4):258-270.

http://dx.doi.org/10.3152/146155109X479440

Haefele, M., and Cliffe-Phillips, K. 2004. Environmental impact assessment made in the North. International Association for Impact Assessment Annual Conference, 26-29 April 2004, Vancouver, British Columbia. $10 \mathrm{p}$.

Hanna, K., and Noble, B.F. 2011. The Canadian Environmental Assessment Registry: Promise and reality. Journal of the German EIA/SEA Association: UVP Report 25(4):222-225.

Hansen, A.M. 2010. SEA effectiveness and power in decision making: A case study of aluminium production in Greenland. $\mathrm{PhD}$ thesis, Institut for Samfundsudvikling og Planlægning, Aalborg University.

- 2011. Strategic environmental assessment (SEA) as a means to include environmental knowledge in decision making in the case of an aluminum reduction plant in Greenland. Journal of Environmental Planning and Management 54(9):1261 - 1278.

http://dx.doi.org/10.1080/09640568.2011.569523

Hansen, A.M., and Kørnøv, L. 2010. A value-rational view of impact assessment of mega industry in a Greenland planning and policy context. Impact Assessment and Project Appraisal 28(2):135-145.

http://dx.doi.org/10.3152/146155110X498807 
Harrison, C. 2006. Industry perspectives on barriers, hurdles, and irritants preventing development of frontier energy in Canada's Arctic islands. Arctic 59(2):238-242.

http://dx.doi.org/10.14430/arctic355

Heinma, K., and Pöder, T. 2010. Effectiveness of environmental impact assessment system in Estonia. Environmental Impact Assessment Review 30(4):272-277. http://dx.doi.org/10.1016/j.eiar.2009.10.001

Hildén, M. 2005. SEA experience in Finland. In: Sadler, B., ed. Strategic environmental assessment at the policy level: Recent progress, current status and future prospects. Czech Republic: Ministry of the Environment. 55-63.

Hildén, M., and Jalonen, P. 2005. Implementing SEA in Finland further development of existing practice. In: Schmidt, M., João, E., and Albrecht, E., eds. Implementing strategic environmental assessment: Environmental protection in the European Union. London: Springer-Verlag. Vol. 2:159-175. http://dx.doi.org/10.1007/3-540-27134-1_11

Hilding-Rydevik, T. 2006. Environmental assessment effectiveness, quality and success. In: Emmelin, L., ed. Effective environmental assessment tools - critical reflections on concepts and practice. Report No. 1 from the MiStprogramme. Kariskrona, Sweden: Blekinge Institute of Technology. 24-43.

Hokkanen, P. 2001. EIA and decision making in search of each other: The final disposal of nuclear waste in Finland. In: Hilding-Rydevik, T., ed. EIA, large development projects and decision-making in the Nordic countries. Stockholm: Nordregio Report 2001:6. 95-151.

Huebert, R. 1998. New directions in circumpolar cooperation: Canada, the Arctic Environmental Protection Strategy, and the Arctic Council. Canadian Foreign Policy Journal 5(2):37-57. http://dx.doi.org/10.1080/11926422.1998.9673131

Huttunen, A. 1999. The effectiveness of public participation in the environmental impact assessment process - a case study of the projected Sierilä hydropower station at Oikarainen, northern Finland. Acta Borealia: A Nordic Journal of Circumpolar Societies 16(2):27-41. http://dx.doi.org/10.1080/08003839908580496

IAIA and IEA (International Association for Impact Assessment and Institute of Environmental Assessment, UK). 1999. Principles of environmental impact assessment best practice. Fargo, North Dakota: IAIA; Lincoln, United Kingdom: IEA.

IWG (Interagency Working Group on Environmental Justice). 2011. Agency responses to comments received during the 2011 Alaska Forum on the Environment. EJ IWG Community Dialogue, 7-11 February 2011, Anchorage, Alaska. Washington, D.C.: U.S. Environmental Protection Agency. http://www.doi.gov/pmb/oepc/upload/alaska-forum-2011agency-responses.pdf

Jalava, K., Pasanen, S., Saalasti, M., and Kuitunen, M. 2010. Quality of environmental impact assessment: Finnish EISs and the opinions of EIA professionals. Impact Assessment and Project Appraisal 28(1):15-27.

http://dx.doi.org/10.3152/146155110X488826
Jantunen, J. 2011. Evaluation of the Finnish EIA system. 31st Annual Conference of the International Association for Impact Assessment, 28 May-4 June 2011, Puebla, Mexico. 5 p.

João, E. 2005. Key principles of SEA. In: Schmidt, M., João, E., and Albrecht, E., eds. Implementing strategic environmental assessment: Environmental protection in the European Union. London: Springer-Verlag. 3-14.

Johnson, C.L., Boyce, M.S., Case, R.L., Cluff, H.D., Gau, R.J., Gunn, A., and Mulders, R. 2005. Cumulative effects of human developments on Arctic wildlife. Wildlife Monographs 160. $36 \mathrm{p}$.

Juslén, J. 1995. Social impact assessment: A look at Finnish experiences. Project Appraisal 10(3):163-170.

http://dx.doi.org/10.1080/02688867.1995.9726990

Kaltenborn, B.P. 1998. Effects of sense of place on responses to environmental impacts: A study among residents in Svalbard in the Norwegian High Arctic. Applied Geography 18(2):169-189. http://dx.doi.org/10.1016/S0143-6228(98)00002-2

Ketilson, S. 2011. Regional strategic environmental assessment roles and stakes in Arctic oil and gas development. MES thesis, University of Saskatchewan, Saskatoon, Saskatchewan.

Kinn, S.J. 1999. Regional environmental impact assessment experiences from Norwegian petroleum activity. Proceedings from the 3rd Nordic EIA/SEA conference, 22-23 November 1999, Kariskrona, Sweden.

Klein, H., Donihee, J., and Stewart, G. 2004. Environmental impact assessment and impact and benefit agreements: Creative tension or conflict? International Association for Impact Assessment Annual Conference, 26-29 April 2004, Vancouver, British Columbia.

Knotsch, C., and Warda, J. 2009. Impact benefit agreements: A tool for healthy Inuit communities? Ottawa: National Aboriginal Health Organization.

Koivurova, T. 2002. Environmental impact assessment in the Arctic: A study of international legal norms. Burlington, Vermont: Ashgate Publishing.

2008. Transboundary environmental assessment in the Arctic. Impact Assessment and Project Appraisal 26(4):265-275.

http://dx.doi.org/10.3152/146155108X366031

Kumpula, T., Pajunen, A., Kaarlejärvi, E., Forbes, B.C., and Stammler, F. 2011. Land use and land cover change in Arctic Russia: Ecological and social implications of industrial development. Global Environmental Change 21(2):550 - 562. http://dx.doi.org/10.1016/j.gloenvcha.2010.12.010

Kwiatkowski, R.E., and Ooi, M. 2003. Integrated environmental impact assessment: A Canadian example. Bulletin of the World Health Organization 81(6):434-438.

Lajoie, G., and Bouchard, M.A. 2006. Native involvement in strategic assessment of natural resource development: The example of the Crees living in the Canadian taiga. Impact Assessment and Project Appraisal 24(3):211 - 220. http://dx.doi.org/10.3152/147154606781765174 
Lidskog, R., and Soneryd, L. 2000. Transport infrastructure investment and environmental impact assessment in Sweden: Public involvement or exclusion? Environment and Planning A 32(8):1465-1479.

http://dx.doi.org/10.1068/a32228

McCrank, N. 2008. Road to improvement: The review of the regulatory systems across the North. Report to the Honourable Chuck Strahl. Ottawa: Indian Affairs and Northern Development Canada. 141 p.

Meschtyb, N.A., Forbes, B.C., and Kankaanpää, P. 2005. Social impact assessment along Russia's Northern Sea Route: Petroleum transport and the Arctic Operational Platform (ARCOP). Arctic 58(3):322-327.

http://dx.doi.org/10.14430/arctic443

Morgan, R.K. 2012. Environmental impact assessment: The state of the art. Impact Assessment and Project Appraisal 30(1):5-14.

http://dx.doi.org/10.1080/14615517.2012.661557

Morrison-Saunders, A., and Bailey, J. 1999. Exploring the EIA/ environmental management relationship. Environmental Management 24(3):281 - 295.

http://dx.doi.org/10.1007/s002679900233

Mulvihill, P.R., and Baker, D.C. 2001. Ambitious and restrictive scoping: Case studies from northern Canada. Environmental Impact Assessment Review 21(4):363-384.

http://dx.doi.org/10.1016/S0195-9255(01)00079-8

MVEIRB (Mackenzie Valley Environmental Impact Review Board). 2004. Environmental impact assessment guidelines. Yellowknife: MVEIRB.

http://www.reviewboard.ca/upload/ref_library/1195078754 MVE\%20EIA\%20Guidelines.pdf

2005. EIA made in the North: The Mackenzie Valley

Environmental Impact Review Board's submission to the 2005 NWT environmental audit. Yellowknife: MVEIRB.

http://www.reviewboard.ca/upload/ref_library/MVEIRB\%20

Part\%206\%20Audit\%20Submission_1196283198.pdf

- 2008. EIA Practitioners' Workshop - 2008. Yellowknife: MVEIRB.

http://www.reviewboard.ca/upload/ref_library/2008_ PractReport-April18_1208886392.pdf

National Research Council. 2003. Cumulative environmental effects of oil and gas activities on Alaska's North Slope. Washington, D.C.: National Academies Press.

Nellemann, C., and Vistnes, I. 2003. Large-scale environmental dynamics: Assessing processes and impacts. In: Rasmussen, R.O., and Koroleva, N.E., eds. Social and environmental impacts in the North: Methods in evaluation of socioeconomic and environmental consequences of mining and energy production in the Arctic and sub-Arctic. Dordrecht, Netherlands: Kluwer Academic Publishers. 3-6.

Nellemann, C., Kullerud, L., Vistnes, I., Forbes, B.C., Foresman, T., Husby, E., Kofinas, G.P., et al. 2001. GLOBIO (Global methodology for mapping human impacts on the biosphere): The Arctic 2050 scenario and global application. Nairobi, Kenya: United Nations Environment Programme, Division of Early Warning and Assessment.
Newton, S.T., Fast, H., and Henley, T. 2002. Sustainable development for Canada's Arctic and Subarctic communities: A backcasting approach to Churchill, Manitoba. Arctic 55(3):281-290.

http://dx.doi.org/10.14430/arctic711

Noble, B., and Birk, J. 2011. Comfort monitoring? Environmental assessment follow-up under community-industry negotiated environmental agreements. Environmental Impact Assessment Review 31(1):17-24.

http://dx.doi.org/10.1016/j.eiar.2010.05.002

Noble, B.F., and Bronson, J.E. 2005. Integrating human health into environmental impact assessment: Case studies of Canada's northern mining resource sector. Arctic 58(4):395-405. http://dx.doi.org/10.14430/arctic453

2006. Practitioner survey of the state of health integration in environmental assessment: The case of northern Canada. Environmental Impact Assessment Review 26(4):410-424. http://dx.doi.org/10.1016/j.eiar.2005.11.001

Noble, B., and Fidler, C. 2011. Advancing Indigenous community Corporate agreements: Lessons from practice in the Canadian mining sector. Oil, Gas \& Energy Law Intelligence 9(4):1 - 30.

Noble, B., Ketilson, S., Aitken, A., and Poelzer, G. 2013. Strategic environmental assessment opportunities and risks for Arctic offshore energy planning and development. Marine Policy 39:296-302. http://dx.doi.org/10.1016/j.marpol.2012.12.011

OECD (Organisation for Economic Co-operation and Development). 2006. Environmental policy and regulation in Russia: The implementation challenge. Paris: OECD. http://www.oecd.org/env/outreach/38118149.pdf

- 2014. OECD environmental performance reviews: Iceland 2014. Paris: OECD.

O'Faircheallaigh, C. 2007. Environmental agreements, EIA follow-up and Aboriginal participation in environmental management: The Canadian experience. Environmental Impact Assessment Review 27(4):319-342. http://dx.doi.org/10.1016/j.eiar.2006.12.002

Ohsawa, T., and Duinker, P. 2014. Climate-change mitigation in Canadian environmental impact assessments. Impact Assessment and Project Appraisal 32(3):222-233.

http://dx.doi.org/10.1080/14615517.2014.913761

Olsen, A.-S.H., and Hansen, A.M. 2014. Perceptions of public participation in impact assessment: A study of offshore oil exploration in Greenland. Impact Assessment and Project Appraisal 32(1):72-80. http://dx.doi.org/10.1080/14615517.2013.872842

O'Reilly, K. 1996. Diamond mining and the demise of environmental assessment in the North. Northern Perspectives 24(1-4).

Orenstein, M., Fossgard-Moser, T., Hindmarch, T., Dowse, S., Kuschminder, J., McCloskey, P., and Mugo, R.K. 2010. Case study of an integrated assessment: Shell's North Field Test in Alberta, Canada. Impact Assessment and Project Appraisal 28(2):147-157.

http://dx.doi.org/10.3152/146155110X498816 
Ovind, A.K.H., and Sneve, M. 2004. Environmental impact assessment and risk assessment in northwestern Russia - from a Norwegian perspective. Contact Expert Group (CEG) workshop on environmental impact and risk assessment as applied to the dismantling of nuclear submarines and the remediation of sites, 17-19 March 2004, Oxford, United Kingdom. Vienna, Austria: International Atomic Energy Agency. http://www.iaea.org/OurWork/ST/NE/NEFW/CEG/ documents/ws032004_Ovind.pdf

Pölönen, I. 2006. Quality control and the substantive influence of environmental impact assessment in Finland. Environmental Impact Assessment Review 26(5):481-491. http://dx.doi.org/10.1016/j.eiar.2005.11.005

Pölönen, I., Hokkanen, P., and Jalava, K. 2011. The effectiveness of the Finnish EIA system - What works, what doesn't, and what could be improved? Environmental Impact Assessment Review 31(2):120-128.

http://dx.doi.org/10.1016/j.eiar.2010.06.003

Porta, L., and Bankes, N. 2011. Becoming Arctic-ready: Policy recommendations for reforming Canada's approach to licensing and regulating offshore oil and gas in the Arctic. Washington D.C.: The PEW Environment Group.

Prno, J., and Bradshaw, B. 2008. Program evaluation in a northern Aboriginal setting: Assessing impact and benefit agreements. Journal of Aboriginal Economic Development 6(1):61-77.

Prowse, T.D., Furgal, C., Chouinard, R., Melling, H., Milburn, D., and Smith, S.L. 2009. Implications of climate change for economic development in northern Canada: Energy, resource, and transportation sectors. Ambio 38(5):272-281.

http://dx.doi.org/10.1579/0044-7447-38.5.272

Rigina, O. 2002. Environmental impact assessment of the mining and concentration activities in the Kola Peninsula, Russia by multidate remote sensing. Environmental Monitoring and Assessment 75(1):11-31.

http://dx.doi.org/10.1023/A:1014248522919

Ross, W.A. 2004. The independent environmental watchdog: A Canadian experiment in EIA follow-up. In: MorrisonSaunders, A., and Arts, J., eds. Assessing impact: Handbook of EIA and SEA follow-up. London: Earthscan. 178-196.

Saarikoski, H. 2000. Environmental impact assessment (EIA) as collaborative learning process. Environmental Impact Assessment Review 20(6):681-700.

http://dx.doi.org/10.1016/S0195-9255(00)00059-7

Sasvari, A. 2012. Consultation practices and assessment of wind power impacts on indigenous Saami lands. 32nd Annual Meeting of the International Association for Impact Assessment held 27 May-1 June 2012, Porto, Portugal. 4 p.

Sok, V., Boruff, B.J., and Morrison-Saunders, A. 2011. Addressing climate change through environmental impact assessment: International perspectives from a survey of IAIA members. Impact Assessment and Project Appraisal 29(4):317-325. http://dx.doi.org/10.3152/146155111X12959673796001

Solodyankina, S., and Koeppel, J. 2009. The environmental impact assessment process for oil and gas extraction projects in the Russian Federation: Possibilities for improvement. Impact Assessment and Project Appraisal 27(1):77-83.

http://dx.doi.org/10.3152/146155109X430344
Sosa, I., and Keenan, K. 2001. Impact benefit agreements between Aboriginal communities and mining companies: Their use in Canada. Toronto, Ontario: Canadian Environmental Law Association.

Storey, K., and Hamilton, L.C. 2003. Planning for the impacts of megaprojects: Two North American examples. In: Rasmussen, R.O., and Koroleva, N.E., eds. Social and environmental impacts in the North: Methods in evaluation of socioeconomic and environmental consequences of mining and energy production in the Arctic and sub-Arctic. Dordrecht, Netherlands: Kluwer Academic Publishers. 281-302.

Suopajärvi, L. 2013. Social impact assessment in mining projects in northern Finland: Comparing practice to theory. Environmental Impact Assessment Review 42:25-30. http://dx.doi.org/10.1016/j.eiar.2013.04.003

Tedsen, E., Riedel, A., Weingartner, K., Azzolini, R., Guillon, F., Longo, S., Leone, C., Paadar, O., and Leonenko, A. 2014. Gap analysis report: Strategic environmental impact assessment of development of the Arctic. Rovaniemi, Finland: Arctic Centre, University of Lapland.

U.S. DOI MMS 2006. Arctic Ocean outer continental shelf seismic surveys - 2006: Final programmatic environmental assessment. OCS EIA/EA, MMS 2006-038. Anchorage: United States Department of the Interior, Minerals Management Service.

Veiga, M.M., Scoble, M., and McAllister, M.L. 2001. Mining with communities. Natural Resources Forum 25:191-202.

Vlassova, T.K. 2006. Arctic residents' observations and human impact assessments in understanding environmental changes in boreal forests: Russian experience and circumpolar perspectives. Mitigation and Adaptation Strategies for Global Change 11(4):897-909. http://dx.doi.org/10.1007/s11027-005-9023-4

Von Ritter, K., and Tsirkunov, V. 2003. How well is environmental assessment working in Russia? A pilot study to assess the capacity of Russia's EA system. Moscow: Alex Publishing House for the World Bank Group.

Voutier, K., Dixit, B., Millman, P., Reid, J., and Sparkes, A. 2008. Sustainable energy development in Canada's Mackenzie Delta-Beaufort Sea coastal region. Arctic 61(Suppl. 1): $103-110$. http://dx.doi.org/10.14430.arctic105

Wernham, A. 2007. Inupiat health and proposed Alaskan oil development: Results of the first integrated health impact assessment/environmental impact statement for proposed oil development on Alaska's North Slope. EcoHealth 4(4): $500-513$.

http://dx.doi.org/10.1007/s10393-007-0132-2

Wismer, S. 1996. The nasty game: How environmental assessment is failing Aboriginal communities in Canada's North. Alternatives Journal 22(4):10-17.

WWF (World Wildlife Fund). 2005. Where are all the SEAs? Project finance and strategic environmental assessment of major oil and gas developments. Washington, D.C.: WWF US. $32 \mathrm{p}$. 